\title{
VIER TIPES OF MODELLE VIR EVANGELISASIE
}

M. Nel

1. Inleidend

Evangelisasie word op meer as een manier bedryf. Die gevaar is nie denkbeeldig nie dat sekere metodes verabsoluteer word en dat h gemeente byna vasval ir. een of twee maniere. Wat hier volg, is slegs $n$ bekendstelling van vier moont like wyses van evangelisasie sonder dat die modelle beoordeel word - $1 \mathrm{~g}$. deels as gevolg van $\mathrm{h}$ gebrek aan ruimte.

2. Gesinsevangelisasie

2.1 George w. Peters ${ }^{1)}$ het in sy boek breedvoerig en in diepte ingegaan op die Evangelisasiemetodiek van veral "Evangelism in Depth" en "New Life for all". In deel I van sy boek noem hy die verskillende Evangelisasiepatrone van die Nuwe Testament. So byvoorbeeld was daar:

1. Die persoon-tot-persoon metode (Joh. 1:35-30; 3:2-21; Hd. 8:26-28; 9:10-19; Joh. 4:5-25; $21: 15-22)$;

2. Die groep of huis (gesins) metode (Hd. 10:24-48):

3. Informele proklamering van die Evangelie (Hd. 2:1-10; 17:17-31);

4. Bybellesing en -uitleg, dialoog en diskussie (Hd. 9:22-29; 17:2, $10,11,17 ; 18: 4,5)$;

5. Die polemiese boodskappe gebou op historiese gegewens (Hd. 3; 4; 6; 7; 13; 22; 23);

6. Oortuigende apologetiese rede (Areopagus; Hd. 26).

Volgens Peters is die doel van "Saturation Evangelism" presies dit wat die Bybel nou met Evangelisasie bedoel, namlik dat almal die Evangelie moet hoor. Daar moet dus "presentation, penetration and saturation" wees voordat "confrontation" kan plaasvind. In hierdie hele opset is die mobilisering van alle gelowiges van die allergrootste belang. Alle kerke en alle gelowiges moet die Evangelie aan alle mense van hul omgewing en land bekend maak. 
Peters kies dan veral die "Evangelism in Depth" en "New Life for All" bewegings om te toon dat hierdie twee bewegings in bedoeling, plan en metode gebaseer is op "Saturation Evangelism" (Daar is ook ander soortgelyke bewegings soos byvoorbeeld Christ for Al1 (Kongo); National Evangelistic Campaign (Korea); Mobilization Evangelism (Japan). Volgens my oordeel sou die Ned. Geref. Kerk se intensiewe landswye evangelisasie en sendingaksie (1970) goedskiks ook hier inpas. Hierdie aksie is minstens vir sover sy motivering betref grootliks deur Evangelism in Depth beinvloed).

In die derde deel van sy boek kom Peters ${ }^{2)}$ egter terug na die begrip "household Evangelism" en bespreek dit saam met groepbeweging as "potentially the most fruitful avenues of Evangelism God has given us".

\subsection{Wat is dit?}

Volgens Peters is hierdie tipe Evangelisasie van ander (ewe legitieme tipes) te onderskei daarin dat dit die "most basic biblical and cultural approach" is. Hy grond sy betoog hiervoor veral op die prioriteit wat die gesin of familie in die Skrif geniet.

Hy gaan egter nie uit van soos hy dit stel die "covenant idea with its consequent infant baptism" nie, maar verstaan onder "household Evangelism" die volgende: "The principle decision on the part of the father and/or the parents, and in deliberation with the members of the family, that the household ought to become a christian home. Then, either joint ly and simultaneous ly as a family unit, or individually, each member in personal decision relates himself to Christ as personal Savior. Becoming a christian thus becomes a family affair and interest".

Volgens hom is die beginsels hieragter die volgende:

1. Die familie of gesin handel in oorleg met mekaar en in eenheid in verband met hierdie basiese saak.

2. Die beslissing word geneem onder die leiding en begeleiding van die ouers en/of vader.

3. Die beslissing is bewustelik, vrywillig, sonder druk deur die lede, maar met die ondersteuning van die gesin.

2.3 Peters kyk dan redelik volledig na die Nuwe Testament en die gesin, gesinsbekerings en die sogenaamde huiskerke. Behalwe hierdie Bybelse ondergrond het gesinsevangelisasie volgens hom ook nog die volgende voordele: 
1. Dit handhaaf meteen die sosiale eenheid wat God geskep het.

2. Dit dien in besonder die versterking en bewaring van hulle wat begin glo.

3. Dit dien op $n$ besondere wyse die Evangelisering van die gemeenskap.

\subsection{Die hoe van gesinsevangelisasie}

Volgens Peters geld hiervoor die volgende beginsels:

1. Die allereerste voorwaarde is die besef dat "household evangelism and household salvation" die Bybelse ideal en norm in evangelisasie is.

2. Die kerk en sy evangelisasie moet fokus op gesinne en h familie atmosfeer skep. Volgens hom is die bediening meesal enkeling gesentreer en is dit nie gesinsbediening nie-om die waarheid te sê die vraag kan gevra word of die kerk die gesin en familie versterk en opbou.

3. Gesinsevangelisasie moet begin met die ouers en veral, indien enigsins moontlik, met die vader. Al is ons diens ook by geleentheid kinderevangelisasie, jeug-, vroue-evangelisasie - die doel is die familie en nie net die individuele gesinslid nie. Die kerk moet ouers eerbiedig vir wat hulle volgens die skrif is en hulle soveel as moontlik inlig oor wat gedoen word en gedoen is. "Household evangelism cannot bypass the parents" 3 ). Hy herinner in hierdie verband aan soos hy dit noem, "the stupendous blessing and advantages in winning fathers as heads of the household for the Lord" en noem veral die voorbeelde van Noag, Abraham, die vaders in Egipte, Kaleb en talle ander.

$2.5 \quad$ Waardering

2.5.1 Peters se uitgangspunt is Bybels verantwoord. Dit sou net veel sterker fundeer gewees het indien hy nie net uitgaan van die gesin as primêre eenheid in die Skrif nie, maar sou werk vanuit die verbond in sy Bybelse gestalte. Laasgenoemde maak die gesin wesensbelangrik en versterk ' pleit om 'n terugkeer na wat hy noem, "the main stream of God's flow of blessings". 
2.5.2 Peters sê tereg dat hierdie nie al evangelisasiemetode is nie en dat daar ook ander legitieme metodes is. In h verstedelikte en gesekulariseerde samelewing waar duisende nie in gesinsverband leef nie, moet noodwendig ander weë gevolg word - en tog is dit myns insiens korrek om te sê die gesin bly die doel. Dan nie alleen die gesin van die enkeling wat tot geloof kom nie, maar ook die toekomstige, nou nog nie bestaande gesin van die betrokke enkeling.

2.5.3 Die klem op die vader as die deur tot die gesin, verdien besondere vermelding. Tereg sê hy dat dit nie die geweldige taak en invloed van byvoorbeeld die moeder minimaliseer nie. Volgens die Skrif is die vader egter in hierdie verband h sleutelfigur. Hy noem hierdie manier, naamlik deur die vader "God's way" - "and in the long run, it is the fastest and most fruitful way in Evangelism"."

3. "Service Evangelism"

3.1 Richard Stoll Armstrong ${ }^{5)}$ het $h$ boek laat verskyn onder bogenoemde titel. Dit is die beskrywing van hodel wat onder sy leiding in sy gemeente (Oak Lane Presbyterian Church of Philadelphia) gedurende die laat vyftigs en begin sestigs ontwikkel is. Na jare van besinning en ondervinding, predikante-seminare en -kursusse vir gelowiges, het hy sy "programme" onder bogenoemde titel bekend gestel. Die bekende Elmer G. Homrighausen sê in die voorwoord: "This 'program' if it may be so called, confirms our conviction that the best evangelism is done by pastors and peoplein local congregations, and that where pastoral leadership has the vision and the ability and the willingness to work at evangelism theologica1ly, personally, congregationa1ly, and communally, something creative will happpen in the life and work of the church". 6 )

Volgens Armstrong is hierdie model gebore uit die nood van predikante en gemeentes oor hoe om in ons tyd uitdrukking te gee aan die evangelisasieopdrag en -taak van die kerk en die talle daarmee verbandhoudende vrae soos byvoorbeeld hoe bereik jy die vervreemde en hoe vertaal die kerk sy kerklike taal tot verstaanbare taal vir die buitekerklike? 
Die insig het deurentyd by hom gegroei dat die beste manier om belangstelling in Evangelisasie op te bou, is om die gemeente tot geestelike verdieping en blootgewing ("commitment') te lei.

\subsection{Die Model}

Die toerustingsplan wat hy mettertyd ontwerp het ten einde aan bogenoemde motivering te gee, noem hy PROOF ("Probing Responsibly Our Own Faith").

Hy beskou dit as $\mathrm{n}$ metode van evangelisasie en mak nie aanspraak op die metode nie. In h uiters lesenswaardige boek werk hy dan hierdie skema in detail uit. Dit kom daarop neer dat hy die motivering vir en die inhoud van h 15 uur seminaar ten einde die gemeente in diensevangelisasie in te lei, in detail bespreek. Dit kan uiteraard nie hier weergegee word nie. Ek noem daarom die pilare waarop sy seminaar en model rus.

3.2.1 Arnstrong gee deeglik aandag aan die rol van geloof. Nie alleen in die lewe van die wat gered moet word nie, maar ook die geloofsoordrag ("faithsharing") deur die gelowige en watter rol laasgenoemde in die "two-way communication" van evangelisasie speel. Hy sê byvoorbeeld in laasgenoemde verband: "The task of the evangelist is not primarily to argue a case but to state one's beliefs in such a way as to enable others to perceive them to be true" ${ }^{\prime 7)}$. Die grootste gedeelte van die toerustingsseminaar word daarom gewy aan die doel daarvan, naamlik: "To explore the meaning of faith, to experience the reality of faith, to establish a method of sharing faith" ${ }^{8)}$. Hy wy sy hele eerste hoofstuk ${ }^{9}$ ) aan die inhoud van die geloof en die oordrag van dit wat geglo word.

Noemenswaardig is sy standpunt oor die antwoord op die vraag van die ongelowige: Waarom glo jy? Geloof is h gawe van God en geen gelowige kan dit by ' $h$ ander skep nie. Al wat die gelowige kan doen, is om te bevestig waarom jy glo. Wys na die getuienis wat jou geloofsoortuigings bevestig - ale gesag van are Bybel, verhoorde gebede, die wete ("sense") van God se teenwoordigheid; die versadiging van jou lewensbehoeftes en die insigte wat jy verkry het. Hierdie punt is-in hierdie model van "service evangelism" van groot belang. Die gelowige moet iemand wees 
wie se lewe werklik $h$ lewende bewysstuk is van God se reddende genade in Christus 10). "Our task is to show by the way we speak and act that we believe He (JX) is"11).

3.2.2 'n Tweede uitgangspunt van die hele program is die waarheid dat die kerk h "dienende kerk" is. Laasgenoemde weer word bepaal deur die kwaliteit van ons dissipelskap. Om hiertoe te kom, moet Hy, die groot dienskneg, ons doel wees. En so vervul die kerk dan sy twee-voudige taak, naamlik om as diensknegte mekaar te dien en om sodoende die boodskap van Jesus Christus na alle mense deur te gee. Die kerk het hierdie opdrag van sy Heer om in die gestalte van h dienskneg sy profetiese, priesterlike en kommunale funksies te vervul. 'n "Servant Church" in die wêreld vandag moet :

1. in instrument van versoening wees war konflik is

2. ' $\mathrm{h}$ hervormer ("agent of reform") wees waar ongeregtigheid is

3. 'n gemeenskap van medelye wees waar lyding is

4. In simbool van Gods oordeel wees waar korrupsie is

5. in demonstrasie van God se liefde wees waar mense van mekaar verwyder is en teenoor mekaar staan.

3.2.3 Teen hierdie agtergrond verstaan hy dan "service evangelism" soos volg: "Reaching out to others in christian love, identifying with them, caring for them, listening to them, and sharing one's faith with them in such a way that they will freely respond and want to commit themselves to trust, love and obey God as a disciple of Jesus Christ and a member of his servant community, the church"12). Die woord "service" impliseer dan in bogenoemde sin evangelisasie "caring, supportive, unselfish, sensitive, and responsive to human need. It is evangelism done by a servant church, whose people are not to be served but to serve" ${ }^{13)}$. Die hoofstuk waarin hierdie definisie voorkom, is viters lesenswardig. Sekere belangrike onderskeidinge word gemaak en riglyne vir evangelisasie word gegee ${ }^{14)}$.

3.2.4 in Volgende belangrike pilaar vir "service evangelism" wat Armstrong noem, is: "Evangelistic Style". Hier beklemtoon hy dat dit vir 'n getuie belangrik is om gehoor te word (te kan praat); om jouself bloot te stel ("to be vulnerable") en om beskikbaar te wees. Dit gaan om h lewe wat die reuk van Christus versprei, wat nie handeldryf nie, mar opreg is. Die doel is immers om mense te bereik, nie om bekeerdes te tel nie; om mense in hul nood te dien en te bedien. 
3.2.5 "Servica Evangelism" is inderdaad ook om mense op te soek ("visitation Evangelism"). Die besoeker gaan egter on te luister, om te empariseer, om te toon dat hul omgee, ja, om n vriend te word en te wees. (Volgens hom is dit meer as wat genoem word "friendship Evangelism" wat volgens hom nie behoefte-georiënteer is nie. (Cf. 4.- Friendship Evangelism) Wanneer $h$ behnefte (van watter aard ookal) bespeur word, moet die besoeker dit probeer bedien en dit ook aan die leraar en diakonie rapporteer. Howel die begoekers nie alle behoeftes kan ontmoet nie, is dit hulle taak om ten volle vertroud te wees met al die bronne van die gemeente in die bediening aan mense in nood en die ideaal is dat die hele gemeente op een of ander manier by laasgenoemde betrokke moet wees. Die aanvanklike doel van die besoeker is dus diens. Om te getuig, is nie h verborge agenda nie. "The point is not whether to witness for Christ, but when and how to witness"15). in sy opleiding van werkers speel aktiewe luister dan ook h belangrike rol. Hy bou dit uit rondom die begrippe: "compassion", "concentration", "control", "comprehension" (verstaan waar die ander persoon vandaan kom), "clarification" en "comitment" (om te doen wat die liefde eis). Uiteraard kry die besoekspan ook opleiding in gesprekvoering.

\subsection{Voorbereiding van die gemeente vir "proof"}

3.3.1 Dit is nie om die program aan te kondig nie. Die gemeente moet voorberei word deur wat hy noem: "Sharing the dream". Aansluitend hierby kom die voorbereiding deur doelgerigte en beplande prediking. ("Program must be under girded by preaching"). In die prediking moet veral die wese en taak van die gemeente belig word - en in besonder dan die dienskneg gestalte van die gemeente. Wat die evangeliese inhoud van hierdie "dienskneg-wees" beteken, moet oorgedra word - só dat "preekstoel en bank elkeen hul plek in hierdie wese en taak verstaan". Sy raamwerk vir so h preekbeplanning is werd om hier genoem te word:

1. Die prediking moet die geestelike groei van die gemeente (enkeling en geheel) dien, uitdaag, motiveer en bevorder.

2. Saam met hierdie oproep tot oorgawe en groei moet daar periodiek gespreek word oor die verskillende aspekte van die leerstukke oor geloof - betekenis, wese, oorsprong en doel. 
3. Minstens ses preke oor die hoe, wat, waar en wanneer van die "servant church".

4. Verduideliking van "service evangelism".

5. Die verband tussen evangelisasie en sosiale betrokkenheid van die gemeente (Vir Armstrong soos vir baie ander is dit onlosmaaklik verbonde).

3.3.2 'n Volgende aspek van die voorbereiding is on die "Proof" moontlikhede te identifiseer en hulle te nooi. Hy verkies persoonlike uitnodiging ("handpicked").

3.3.3 Ontwikkeling van die ondersteunende sisteem. Hieronder verstaan hy die opbou van die hele res van die gemeente (ampte en andere) om deel te neem aan hierdie bediening en as ' $t$ ware op allerlei wyses op "stand-by" te wees ten einde behoeftes wat ontdek word, te ontmoet. Hierdie diens gaan ook oor gemeente grense in wat hy noem "the ministry of the church-incommunity"16).

3.3.4 Na die eerste seminaar volg dan h goed gekontroleerde weeklikse besoekprogram in die gemeenskap. Telkens word terugrapporteer. Die besoekersgroep raak mettertyd dan betrokke by drie tipe besoeke, te wete "probe-calls" (eerste besoeke), "follow-through" (waar reeds tevore besoek afgelê is) en "pastoral-calls" (aan persone wat reeds lidmate is of geword het en wat tekens van afdwaling toon) ${ }^{17)}$. Die name en behoeftes van hulle wat besoek word, word gekaart en $h$ spesifieke persoon is verantwoordelik om telkens deur hierdie kaarte te werk en besoekopdragte vir die besoekerspan word hieruit gemaak.

In al hierdie besoeke word van gepaste literatuur gebruik gemaak. Veel word byvoorbeeld gemak van die gemeente bulletin.

$\mathrm{Na}$ elke besoeksessie is daar ' $\mathrm{n}$ kort byeenkoms ("afterglow"). Hier word die ondervinding van die aand met mekaar gedeel en word die besoekers onderling opgebou en bemoedig.

Volgens Armstrong het hierdie besoekprogram langdurige effekte vir die besoekers, die gemeente en die gemeenskap. 
4. "Friendship-Evangelism"

4.1 In sy boek met bogenoemde titel beskryf die Mennoniet Arthur G. Mcphee "Friendship Evangelism" as "the caring way to share your faith" ${ }^{18)}$.

Volgens Myron S. Augsburger in die voorwoord word daar te dikwels aan evangelisasie gedink as h funksie, eerder as h "fellowship". Die indruk word dan dikwels geskep asof gelowiges mense liefhet, maar persone haat. "Friendship Evangelism" daarenteen beteken deelgenootskap in h verhouding van liefde.

Uitgaande van die kerk as die "goeie nuus mense" betoog Mcphee dat dit in die Nuwe Testament nie nodig was om oor motivering en metode ten opsigte van evangelisasie te praat nie. Jesus het by niemand gepleit om sy getuienis te wees nie. Sy opdrag was hul motivering. Die "alle nasies" was hul visie en dit definieer ook die grense van die taak van die kerk. Volgens hom is dit om hierdie rede noodsaaklik dat gemeentes moet wegkom van die sogenaamde "kom-struktuur" en werk aan 'n Bybelse "gaan-struktuur". "Every disciple of Jesus Christ is called to befriend the good, the bad and the ugly of this world".

Terselfdertyd is dit ook die inhoud van die boodskap van die gelowige, naamlik om mense tot dissipelskap van Jesus Christus te roep en dit geskied in $h$ verhouding van vertroue en vriendskap. In hierdie verband neem hy dan sterk standpunt in teen metodes wat neerkom op "easy believism" en wat nie rekening hou met die Bybelse eise vir dissipelskap nie.

4.2 In h hoofstuk wat lesenswaardige momente en inligting bevat, onderskei hy tussen hoek-visvangs en net-visvangs. Die eksegetiese onderhou is nie bo verdenking nie, maar die punt wat hy mak, naamlik dat dit by die vangs van mense nie gaan om trofeë en aas nie, is wel van betekenis. Vriendskapevangelisasie is evangelisasie war werklik omgegee word vir mense en is in dié sin lang-termyn evangelisasie. Dit is evangelisasie waar persone belangrik is, hulle agtergrond, hulle hartseer en hul behoeftes (wat hierdie punt betref stem dit ooreen met die uitgangspunt van Armstrong in Service Evangelism). 
Volgens hom is daar belangrike besware teen wat hy soms noem "Careless Evangelism". (Volgens hom kan direktiewe metodes slegs vir 8-10\% lidmate geleer word). Wat by lasgenoemde gemis word, is juis dit wat in vriendskapevangelisasie sterk beklemtoon word. Dinge soos oortuiging van sonde; die minimalisering van die eis van berou en bekering; goedkoop genade; valse sekerheid; druk vir h beslissing voor die persoon daarvoor ryp is.

4.3 Soos verwag kan word, word die eis van die liefde in "Friendship Evangelism" baie sterk beklemtoon.

4.4 Terug by die argument dat gelowiges in die tyd van die vroeë kerk so spontaan getuig het (sonder dat hul gesoebat, opgewek en georganiseer moes word), noem hy in paar "barriers" wat dit vandag moeilik maak. Hy noem onder andere:

1. Die toenemende universalisme. Gelowiges twyfel aan die bestaan van die hel en die verlorenheid van mense en so word die nodigheid om die geloof in Christus te deel, verkleineer.

2. Beperkte praatvermoë.

3. Beperkte verstandelike vermoë.

4. Vrees om verwerp te word.

5. Beperkte krag of moed.

Die punt waarom dit egter gaan is eerder "showing". Daar is duisende maniere om elke dag liefde te betoon teenoor almal op die pad. Daarom weeg dit wat die christen $\underline{\text { is }}$ so swaar. Sy lewe moet as 't ware Christus "present"maak en in dié sin "evangelism must be incarnational to be authentic"19)

4.5 h Ander voorwaarde in hierdie metode of manier van lewe is wat die Amerikaners noem: "Earning the right to be heard". En dit roep om die opbou van $h$ verhouding warin jy jou assosieer en identifiseer met die medemens. En hiervoor is h A.B.C. plan nodig: "Acceptance, Benevolence and Caring". In die opbou van hierdie verhoudings, spontaan en langs die pad van elke dag se christenwees is die volgende van belang: 
1. Leer om na mense te luister.

2. Stel opreg in jou potensiële vriend belang.

3. Ontwikkel ("cultivate") vriendskap. Dit neem tyd, maar dit is die moeite werd.

4. "Share your faith". Gewoonlik kom so h geleentheid as gevolg van vrae.

4.6 Persone wat langs hierdie weg gewen word, moet terwyl die vriendskap ontwikkel word en ook daarna ingelei word in die lewe van gemeenskap met die ander gelowiges. Die aanvanklike betrokkenheid by ' $\mathrm{n}$ klein groep word baie sterk beklemtoon. Vriendskap, aandag en belangstelling moet ook nie ophou na oorgawe en opname in die gemeente nie. Soos hy dit stel: dit is nie h saak van "follow-up" nie, maar "follow-through".

5. "Target-group Evangelism"

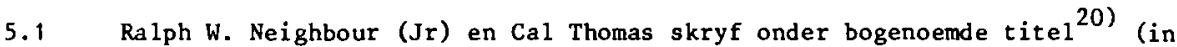
geselstrant met h sekere Fred wat oor hierdie tipe evangelisasie navraag doen), in lesenswaardige boek oor "reaching people where they are".

Dit vertel die verhaal van h Baptiste gemeente wat sedert 1969 nagevors het op watter wyse hulle hul roeping ten beste in h see van woonstelblokke en pragtige huise, kon vervul. Hoe dra jy die Evangelie van Christus na die "unchurchables"? Die boek is h verslag van wat in die gemeente gebeur. In die $\sin$ is dit die vyfde in $h$ ry van publikasies wat die inhoud van die toerustingskursus sowel as die storie van die begin af vertel. ${ }^{21}$ )

Die betrokke tipe evangelisasie dra ook die naam "Touch Ministries" of "Life-Style Evangelism". Die bediening word aangepak met h swaar las op die hart van die gemeente, naamlik dat 27 van die bevolking per jaar die kerk verlaat en dat slegs $38 \%$ nog $n$ betekenisvolle verband met die kerk of sinagoge het. En dit gaan vir Neighbour om die $62 \%$ "Outsiders". Die vraag is hier eweneens die "kern-strukture" van die tradisionele kerk. En die feit: Hulle kom nie! Om die gemeente sover te kry on te gaan, het hul in Houston vyf jaar se harde werk gekos en nou is daar $h$ gemeente met $h$ "gaan struktuur". 
Gaan, is vclgens hierdie metode egter nie die direkte konfrontasie gedagte nie. Volgens Neighbour reageer ont rent $5 \%$ van almal wat met laasgenoemde metode benader word. Die sleutel om mense te bereik, is eerder om hul nood en behoefte te ontdek en om Christus as die groot lewensantwoord aan te bied en in die sin definieer hy dan Target-Group Evangelism as: "scratching people where they itch", 22) want as christene die werklike behoeftes van die buitekerklikes ontdek en ontmoet sal hul as vriende verwelkom word.

5.2 Om dit te verwesenlik is die TOUCH bediening ontwikkel (Transforming Others Under (hrist's Hand). Christene is "people who care, without strings attached" 23 ).

5.3 Hierdie bediening (hy verkies die woord bediening bo program) verskil van die tradisionele evangelisasie-metodes op drieërlei wyse:

1. Die effek van die lewende Christus op gelowiges, is die fokuspunt van die getuienis eerder as byvoorbeeld die verspreiding van traktaatjies of kort "canned speeches". Daarom vra hierdie bediening om Gees vervulde en Gees-geleide gelowiges.

2. Die bediening bring mee die betrokkenheid van klein groepe eerder as een-tot-een bediening.

3. Die bediening maak gebruik van $n$ opbouende benadering waarin gelowiges en ongelowiges $h$ groepsverhouding met mekaar oor h hele aantal weke ontwikke1 ( 1 gelowige tot 5 ongelowiges).

Sy meer omvattende definisie van hierdie bediening lui soos volg: "TOUCH is a ministry of men and women who are commissioned by the local congregation to become ministers of Christ in the greater community of unreached persons. The church sponsors, directs, subsidizes, receives reports from each TOuCH ministry" 24 ).

5.4 Die verskillende moont likhede vir "Target-Groups" is byna onbeperk. So is daar in die gemeente "TOUCH ministries" aan geskeides;

"house fellowship" vir ouers met gestremde kinders; bediening aan alkoholiste, vir kampeerders by die "trailer park"; "TOUCH club" vir kinders in woonstelblokke; "Rap-ins" vir tieners; bediening van mans aan die kroeë, vulstasies ens. Tereg sê Neighbour dat daar geen einde aan moontlikhede is nie. Dit hang van die tipe gemeenskap af waar die gemeente is. So is daar byvoorbeeld 
'n groep wat vir vreemdes Engels leer.

'n Baie belangrike beginsel agter hierdie groepe is die gawes wat die Gees aan die lidmate gee. So is h geneesheer byvoorbeeld ten volle betrokke by die bediening aan die verslaafdes. Volwassenes met die gawe om met die jeug te werk by die "Rap-ins for Teens".

\subsection{Voorbereiding van die gemeente}

5.5.1 Neighbour meen dat die voorbereiding minstens een jaar en langer duur. Hy warsku ook herhaaldelik dat dit stadig gaan, maar dit is soos die tyd wat $h$ boer neem om sy lande reg te maak en te saai. Dit is noodsaaklik. Mense verander stadig en hierdie bediening vereis dat mense die gemeente en sy evangelisasie taak anders moet leer sien. (Vir sommige duur dit 6 jaar). Hy verdeel die voorbereiding in twee fases:

\subsubsection{Die inwendinge of na binne gekeerde verandering}

Dit gaan in hierdie bediening eers om "being" en dan om "doing". Sterk beklemtoon hy die verhouding wat tussen gelowiges in hierdie tyd opgebou moet word. Mense en boeke verander ons lewens en in hierdie tyd moet albei meewerk. Vyf onderwerpe moet minstens met die gemeente gedeel word. (Hul maak baie van naweekkonferensies gebruik):

1. Die enigste bron van versekering.

2. Die twee nature van die gelowige.

3. Die drie aspekte van verlossing (verlossing van die straf op sonde, die mag van die sonde en die teenwoordigheid van sonde - laasgenoemde eskatologies).

4. Vier moontlike bronne van gesag (Die kerk, die Bbel, die intellek en ondervinding).

5. Die wese van die kerk en die gawes (hier beklemtoon hy in besonder die dienskneggestalte van die gelowige).

\subsubsection{Die reis na buite}

Dit beteken allereers $h$ letterlike verkenning van die gemeenskap. Die nood van mense waar hulle is, moet eers raakgesien word. Daarom neem hy mense straat toe; gaan sit in h $\mathrm{kroeg}$, in $\mathrm{h}$ disco, by die vulstasie, waar mense naweek hou, enr. Vra vrae. Dit word $n$ ondersoek na die godsdienstige houding en ged van mense. Hy ag hierdie ontdekking van sekere groepe 
in die gemeenskap se behoeftes en leefwêreld van die allergrootste belang. Vanuit hierdie kontakte probeer elke christen dan vir hom $h$ klein groep vir gesprek opbou ( 1 tot 5 of 2 tot 6). Dit neem lank. Hy suggereer ses maande vir hierdie stadium. Wanneer die groepe egter eers gevestig is, is daar volgens die ondervinding van die gemeente 'n gedurige stroom van mense wat na Christus en die kerk terugkeer.

5.5.4 Die groepe word vir minstens tien weke geskeduleer - een en h half uur per keer. Die balans tussen gewone "sharing" en "inhoud" (bv. Bybelstudie) word soos volg uitgedruk:

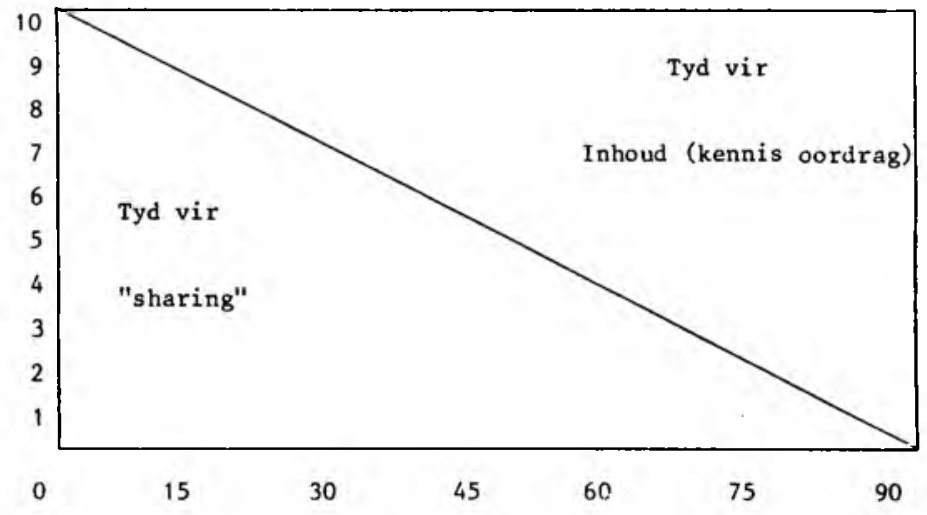

5.5.5 Laat my weer beklemtoon dat hy dit sterk stel dat lidmate hul deur die Gees tot die onderskeie bedieninge geroepe moet voel. Persone word nie geplaas nie, maar beweeg spontaan in hul eie belange groepe (soos bv. n ekonoom) of waar die Gees hul heen roep in ooreensteming met hul gawes of eie behoeftes. So is die leier van die groep vir ouers met gestremde kinders self h ouerpar wat deur jare se worsteling hul eie gestremde kind as gawe van God aanvaar het.

5.5.6 Indie res van die boek word $h$ aantal van hierdie bedieninge meer in detail beskryf en elke leraar behoort deeglik daardeur te werk. Hier is sonder twyfel $\mathrm{n}$ bedieningsmoont likheid (nie alleen ten opsigte van evangelisasie nie) wat ernstige oorweging verdien.

5.5.7 Die groepe lei altyd weer tot die groter gemeenskap van die gemeente. Die gemeente ervaar ook permanente groei. In 1974 het die lidmatetal verdubbel. Intussen is $n$ TOuCH-sentrum opgerig wat gedurende die hele 
week benut word. Die gebou sluit in h spreekkamer (o.a. vir h psigiater), skaatsbaan, untspanningsgeriewe, koffiekamer en baie meer. Sodoende word die "gaan struktuur" van die gemeente gedien en staan daar nie ' gebou wartieen mense slegs op Sondae kom nie.

\section{NOTAS}

1. Saturation Evangelism, Grand Rapids/Michigan 1970.

2. A.w., 145.

3. Peters, a.w., 162 .

4. Peters, a.w., 166.

5. Service Evangelism, Phi ladelphia 1979.

6. A.w., 12 .

7. A.w., 22.

8. A.w., 134.

9. A.w., $2:-37$.

10. A.w., 33.

11. A.w., 37 .

12. A.w., 53 .

13. Ibid.

14. A.w., 5t-70.

15. A.w., 82 .

16. A.w., 160.

17. A.w., 166.

18. Friendship Evangelism, Michigan 1978, 9.

19. A.w., 77.

20. Target-group Evangelism, Nashville 1975.

21. Cf., o.a. The touch of the Spirit, Nashville 1972; Journey into Life-style Evangelism, Baptist Brotherhood Commission, 1974.

22. A.W., 20 .

23. A.w., 23.

24. A.w., 22 . 